\title{
POTENTIAL USE OF NIR AND VISIBLE SPECTROSCOPY TO ANALYZE CHEMICAL PROPERTIES OF THERMALLY TREATED WOOD
}

\author{
Elaine Cristina Lengowski ${ }^{1,}$, Graciela Inês Bolzon de Muñiz², Umberto Klock², \\ Silvana Nisgoski ${ }^{2}$
}

\begin{abstract}
The modification of wood by thermal treatments produces characteristic changes in its chemical composition and surface color and can improve the structural and esthetic quality. The objective of this paper is to evaluate the potential of near infrared and visible spectroscopy to predict the modifications in chemical composition of Eucalyptys grandis and Pinus taeda after thermal treatment. Near infrared and visible spectra were collected directly on the longitudinal surface of wood samples. The thermally modified wood of both species showed higher content of lignin and extractives than the untreated wood. There was darkening of thermally modified wood, as a result of chemical modification caused by heat. The Near infrared/visible technique identified the groups that were modified by treatment. NIR and visible spectroscopy can be used to predict chemical composition of natural or thermally treated Eucalyptus grandis and Pinus taeda.
\end{abstract}

Keywords: Chemical analysis, Eucalyptus grandis, Pinus taeda, thermal modification, wood color, wood composition.

\section{INTRODUCTION}

The application of thermal treatment in the wood industry has been growing in recent years. Studies have reported that heat process can modify some properties of wood as natural durability, dimensional stability, hygroscopicity (Olarescu et al. 2014, Militz and Altgen 2016, Pertuzzatti et al. 2016, Huang et al. 2018) and mechanical properties (Kuzman et al. 2015, Militz and Altgen 2016). Differences have also been verified in the equilibrium moisture content, volumetric swelling and chemical composition of juvenile and mature wood (Gonzáles-Peña et al. 2009, Esteves et al. 2011, Severo et al. 2012). The review of Esteves and Pereira (2009) reported changes in mass loss, chemical composition, anatomical structures, equilibrium moisture, dimensional stability, durability, mechanical properties, wettability, weathering, finishing, gluing, color and quality control. These results were confirmed in Pinus elliottii (Conte et al. 2014, Pertuzzatti et al. 2016), in eucalyptus species (Garcia et al. 2014, Zanuncio et al. 2014a, Zanuncio et al. 2014b, Zanuncio et al. 2014c), and other commercial wood as Lecythis pisonis (De Paula et al. 2016), Simarouba amara (Freitas et al. 2016) and Tectona grandis (Méndez-Mejías and Moya 2016).

One important change in heat-treated wood is its generally darker appearance, which can be explained by the combination of several factors: (a) the dissolution, oxidation and decomposition of the extractives and other chemical components; (b) formation of oxidative products, such as quinones and products of degradation of hemicelluloses and lignin, which migrate to the wood surfaces; (c) the

\footnotetext{
${ }^{1}$ Federal University of Mato Grosso, Department of Forest Engineering, Cuiabá, Brazil.

${ }^{2}$ Federal University of Paraná, Laboratory of Wood Chemistry, Department of Forest Engineering and Technology, Federal University of Parana, Av. Lothario Meissner, Jardim Botânico, Curitiba-PR, Brazil.

•Corresponding author: elainelengowski@yahoo.com.br

Received: 10.05.2017 Accepted: 07.05.2018
} 
removal or migration of extractives and nutritive compounds such as low molecular weight sugars and amino acids towards the wood surfaces; and (d) the relative increase in the lignin content after the treatment, mainly due to the degradation of the hemicelluloses (Torres et al. 2012, Cademartori et al. 2013, Stangerlin et al. 2013, Bekhta et al. 2014). The wood with large quantities of extractives soluble in water present more intense changes of color after the treatment (Varga and Van Der Zee 2008). Some literature report that in hardwoods, color modification is less pronounced than in softwoods in function of different lignin content because this component is responsible for $80-95 \%$ of light absorbance in wood (Mitsui 2004, Moura and Brito 2011). Higher extractive contents and higher reactivity of hemicelluloses and lignin can accelerate the degradation process at low temperature; on the other hand, organized cellulose regions may promote a slow degradation process (Poletto et al. 2012).

The natural pine wood color (pale yellow) is not stable to light exposure, becoming grayish after exposure to sunlight, and when exposed in air it becomes whitish. Thermal treatment confers a reddish brown color, which is appreciated by most consumers (Esteves et al. 2008, Zanuncio et al. 2014b). Thermal modification has potential to improve the structural and esthetic quality of wood, in particular that from Pinus spp. and Eucalyptus spp. species with good properties, fast growing, but sometimes with unattractive coloration. In addition, the use of cultivated species to replace native wood species is necessary to preserve and reduce the pressure on the native forest.

Application of near-infrared spectroscopy to study thermally treated wood has revealed a close relationship between the chemical changes of thermally modified Fagus sylvatica samples and the corresponding NIR spectra (Schwanninger et al. 2004), alterations on phenolic, carbonyl, carboxyl, acetyl and hydroxyl groups (Mitsui et al. 2008, Chen et al. 2014, Li et al. 2015, Méndez-Mejías and Moya 2016), and changes in pine and eucalyptus properties (Esteves and Pereira 2008). It has potential for use in quality control of thermally modified wood, because it allows evaluation of several wood properties by obtaining a single spectrum (Bächle et al. 2010, Méndez-Mejías and Moya 2016).

Therefore, the objective of this paper is to evaluate the modifications in chemical composition of Eucalyptus grandis and Pinus taeda based on near infrared and visible spectroscopy of solid samples. This paper is the first to evaluate the spectral analyses from visible spectroscopy to predict changes on chemical composition after the thermal treatment of wood. The consolidate technical to analyze this is NIR spectroscopy, however, if we can use the visible spectroscopy we can evaluate two properties in one equipment, color parameters and quality of treatment applied on the wood, and also the colorimeter is more cheaper.

\section{MATERIALS AND METHODS}

\section{Materials}

Trees of Eucalyptus grandis W. Hill and Pinus taeda L. came from plantations with age of 18 years. Boards with dimensions of $110 \times 20 \times 3 \mathrm{~cm}$ respectively in length, width and thickness were thermally treated. Wood untreated and thermally modified (Figure 1), came from the company TWBrazil, located in Ponta Grossa, Parana state, Brazil. The thermal modification was performed by the VAP HolzSysteme ${ }^{\circledR}$ process, applying heat of $160{ }^{\circ} \mathrm{C}$ in a saturated steam atmosphere with efficient elimination of oxygen. The treatment was done in five stages: an initial heating ramp of $0,76{ }^{\circ} \mathrm{C} \cdot \mathrm{min}^{-1}$ until constant temperature $\left(110^{\circ} \mathrm{C}\right), 25$ minutes at this temperature; a second ramp of $0,20{ }^{\circ} \mathrm{C} \cdot \mathrm{min}^{-1}$ until the final temperature $\left(160{ }^{\circ} \mathrm{C}\right) ; 45$ minutes at maximum temperature; and natural cooling. The total time of the process was about 16 hours, carried out in two 8-hour heating-cooling cycles. Four boards per treatment were analyzed. One sample of each board, with dimensions of $20 \mathrm{~cm}$ (length) $\mathrm{x}$ $8 \mathrm{~cm}$ (width) and $3 \mathrm{~cm}$ (thickness), were extracted on the middle of board and applied for color and spectroscopy analysis. 


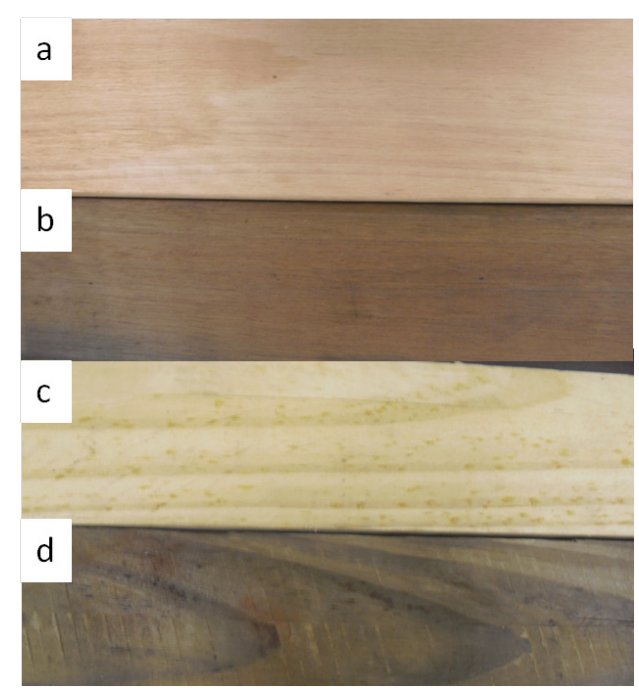

Figure 1: Boards of Eucalyptus grandis: (a) natural and (b) thermally modified; and Pinus taeda: (c) natural and (d) thermally modified.

\section{Methods}

\section{Near Infrared spectroscopy}

In each sample, eight spectra were collected directly on the longitudinal surface, four in radial section and four in tangential section, in a room with temperature of $23 \pm 2{ }^{\circ} \mathrm{C}$ and relative humidity of $60 \%$. A total of 128 spectra were obtained, 32 by treatment. The infrared analyses were performed with a Bruker Tensor 37 spectrometer (Bruker Optics, Ettlingen, Germany) equipped with an integrating sphere and operating in reflectance mode. Spectra were obtained at 64 scans with resolution of $4 \mathrm{~cm}^{-1}$ and a spectral range of $10000-4000 \mathrm{~cm}^{-1}$ transformed to $\mathrm{nm}$ in Opus version 6.5 program (Bruker Optics). For analysis, the spectra were averaged for each surface, i.e., 2 in each radial and 2 in each tangential section in one sample, and 16 were evaluated for each treatment.

\section{Color measurements}

Wood color was measured with a Konica Minolta CM-5 spectrophotometer coupled to a computer, with adjustment to a D65 light source and $10^{\circ}$ observation angle (CIE-Lab standard). The reflectance data were obtained with a spectral range from $400-750 \mathrm{~nm}$. Eight spectra were collected per sample directly on the longitudinal surface (4 in radial and 4 in tangential section). A total of 128 spectra were obtained, 32 for each species and treatment, and analysis was performed with all spectra.

The following color parameters were measured according to the CIELAB: color space: lightness $\left(\mathrm{L}^{*}\right)$, green-red coordinate $\left(\mathrm{a}^{*}\right)$, blue-yellow coordinate $\left(\mathrm{b}^{*}\right)$, color saturation $\left(\mathrm{C}^{*}\right)$, and hue angle (h). A colorimetric scan of the surface of these samples was performed randomly, with a total of 10 readings per sample (radial/tangential section). The values of color saturation (C) and hue angle (h) were calculated by Equation 1 and Equation 2:

$$
\begin{aligned}
& C^{*}=\sqrt{a^{* 2}+b^{* 2}} \\
& h=\arctan \left(\frac{b^{*}}{a^{*}}\right)
\end{aligned}
$$


The changes between natural and thermally modified wood were analyzed based on DE (total color variation), calculated by Equation 3:

$$
\Delta E=\sqrt{\Delta L^{*^{2}}+\Delta a^{*^{2}}+\Delta b^{*^{2}}}
$$

\section{Spectral analysis}

The Unscrambler X chemometric program (version 10.1, from CAMO Software AS) was used to analyze the data. Exploratory modeling was done by analyzing the score and loading graphs obtained by principal component analysis (PCA) to verify possible differences in natural and thermally modified wood. PCA was based on algorithm NIPALS and cross validation with centered data. PCA is widely applied for analysis of spectroscopy data as a preliminary step to observe variance structure of data and visualization of its natural clustering, followed by multivariate methods (Acquah et al. 2016).

Partial least squares (PLS) with cross validation were applied to build models for chemical property prediction. The adequate number of factors was evaluated based on lowest error of prediction and highest correlation coefficient, without eliminating samples in building the models. The main aim of PLS is analysis of numerous X-variables (spectra data) to predict response variables (chemical composition). The most important information is the number of principal components (PCs) selected, which will be included in regression models to result in a lower prediction error, that is, to present the lowest difference between references and estimated values (Kumar et al. 2014).

In spectral analysis, pretreatment of data is important to eliminate noise and remove physical phenomena in order to improve the subsequent analysis. Multiplicative scatter correction (MSC) pretreatment was applied to the data, and in this case, the mean of the calibration set was used as the reference for the test set. MSC is a scatter-corrective pretreatment technique applied to reduce the variability between samples due to scattering and also to adjust for baseline shifts (Fearn et al. 2009).

Samples were randomly divided into 96 for calibration (75\% of spectra) and 32 for external prediction (25\% of spectra). Spectral analysis was based on ASTM E1655-05-2012 (ASTM 2012). Although number of samples is few, the objective of the manuscript is to test the potential of technique to predict chemical changes. For NIR, literature report good results, but for reflectance spectra of visible light available data are related to physical properties.

\section{Chemical analysis}

Samples of natural and thermally modified wood were ground in a Wiley mill (De Leo, Porto Alegre, Brazil) and classified. The material between 40-60 mesh was analyzed. Chemical characterization was done in triplicate in accordance with TAPPI methods (TAPPI T204-om97-2004 for total extractives; TAPPI T222-om02-2004 for lignin content; TAPPI T211-om02-2004 for ash content. Holocellulose content was calculated by difference from total extractives, insoluble lignin and ash content.

\section{Statistical analysis}

Statistical analysis was applied to identify differences in chemical composition and color between natural and thermally modified wood. Comparisons of means were performed by the Tukey test at $5 \%$ significance level.

\section{RESULTS AND DISCUSSION}

\section{Chemical composition}

Thermal treatment resulted in an increase in extractives $(44,61 \%$ and $27,56 \%)$ and lignin content (36,18\% and $9,08 \%)$, but reduced holocellulose content $(15,68 \%$ and $4,41 \%)$, respectively for 
Eucalyptus grandis and Pinus taeda (Table 1). Heat treatment causes degradation of hemicelluloses (Brito et al. 2008), while solubilization of water extractives can contribute to increase these compound's content (Esteves et al. 2011, Tong and Zhang 2016). Lignin condensation reactions with other cell wall components results in crosslinking and contributes to an apparent increase in its content. On the other hand, extractives can be degraded or leave the wood and new compounds can be formed (Esteves and Pereira 2009, Tong and Zhang 2016).

Table 1: Mean (standard deviation) of wood chemical composition.

\begin{tabular}{|c|c|c|c|}
\hline Material & $\begin{array}{c}\text { Extractives } \\
(\mathbf{\%})\end{array}$ & $\begin{array}{c}\text { Lignin } \\
(\mathbf{\%})\end{array}$ & $\begin{array}{c}\text { Holocellulose } \\
(\mathbf{\%})\end{array}$ \\
\hline Eucalyptus grandis - natural & $6,77 \mathrm{a}$ & $22,06 \mathrm{a}$ & $71,17 \mathrm{a}$ \\
$(0,90)$ & $(5,05)$ & $(1,54)$ \\
\hline \multirow{2}{*}{ Eucalyptus grandis $-160{ }^{\circ} \mathrm{C}$} & $9,79 \mathrm{~b}$ & $30,07 \mathrm{~b}$ & $60,15 \mathrm{~b}$ \\
& $(0,66)$ & $(3,46)$ & $69)$ \\
\hline Pinus taeda - natural & $2,54 \mathrm{c}$ & $27,97 \mathrm{~b}$ & $(1,69 \mathrm{a}$ \\
& $(0,99)$ & $(3,94)$ & $66,26 \mathrm{c})$ \\
\hline Pinus taeda $-160^{\circ} \mathrm{C}$ & $3,24 \mathrm{~d}$ & $30,50 \mathrm{~b}$ & $(1,29)$ \\
\hline
\end{tabular}

*Equal letters in a column indicate no statistical difference by the Tukey test at $5 \%$ probability.

The increase in lignin content has also been observed in Eucalyptus citriodora (Silva 2012), Eucalytpus saligna and Pinus caribaea var. hondurensis (Brito et al. 2008), Pinus taeda (Silva 2012), Pinus elliottii (Severo et al. 2012) and Pinus spp. (Tong and Zhang 2016), while it remained equal for Pinus caribaea with treatment of $200{ }^{\circ} \mathrm{C}$ (Poubel et al. 2013). For extractives, reduction in Eucalyptus saligna (Brito et al. 2008), Eucalyptus citriodora (Silva 2012) and Eucalyptus grandis (Zanuncio et al. 2014b), and increase in Pinus caribaea var. hondurensis (Brito et al. 2008), Pinus caribaea (Poubel et al. 2013), Pinus elliottii (Severo et al. 2012) and Pinus spp. (Tong and Zhang 2016) have been reported. Esteves et al. (2008) studied extractives content in Eucalytpus globulus and observed an increase at the start of treatment. Reduction in holocellulose content has also been observed in Eucalyptus grandis (Zanuncio et al. 2014b), Pinus caribaea (Poubel et al. 2013), Pinus elliottii (Severo et al. 2012) and Pinus spp. (Tong and Zhang 2016). Also differences between juvenile and mature wood were reported (Severo et al. 2012). Negative correlation between Klason lignin and luminosity was found for Eucalyptus grandis and Pinus caribaea var. hondurensis (Moura and Brito 2011).

\section{Colorimetry}

The results of color measurements as well as multiple comparisons between means by the Tukey test are reported in Table 2.

Table 2: Colorimetric parameters of Eucalyptus grandis and Pinus taeda with and without thermal modification.

\begin{tabular}{|l|c|c|c|c|c|}
\hline Material & $\mathbf{L}^{*}$ & $\mathbf{a}^{*}$ & $\mathbf{b}^{*}$ & $\mathbf{C}^{*}$ & $\mathbf{h}$ \\
\hline Eucalyptus grandis - natural & $65,75 \mathrm{a}$ & $13,03 \mathrm{a}$ & $20,46 \mathrm{a}$ & $24,27 \mathrm{a}$ & $57,62 \mathrm{a}$ \\
\hline Eucalyptus grandis $-160^{\circ} \mathrm{C}$ & $36,43 \mathrm{~b}$ & $8,64 \mathrm{~b}$ & $13,07 \mathrm{~b}$ & $15,68 \mathrm{~b}$ & $56,40 \mathrm{~b}$ \\
\hline Pinus taeda - natural & $77,32 \mathrm{c}$ & $6,71 \mathrm{c}$ & $30,05 \mathrm{c}$ & $30,81 \mathrm{c}$ & $77,53 \mathrm{c}$ \\
\hline Pinus taeda $-160^{\circ} \mathrm{C}$ & $52,64 \mathrm{~d}$ & $9,51 \mathrm{~d}$ & $23,71 \mathrm{~d}$ & $25,56 \mathrm{a}$ & $68,18 \mathrm{~d}$ \\
\hline
\end{tabular}

Lightness $\left(\mathrm{L}^{*}\right)$, green-red coordinate $\left(\mathrm{a}^{*}\right)$, blue-yellow coordinate $\left(\mathrm{b}^{*}\right)$, saturation $\left(\mathrm{C}^{*}\right)$ and hue angle $(\mathrm{h})$. Equal letters in a column indicate no statistical difference by the Tukey test at $5 \%$ probability.

The results indicate a significant reduction in lightness $\left(\mathrm{L}^{*}\right)$ in both species after thermal treatment. In Eucalyptus grandis, the decrease was more pronounced $(44,6 \%)$ than in Pinus taeda $(31,9 \%)$, probably in function of chemical groups of extractives and its volatilization. The same behavior has been observed in other studies with Eucalyptus grandis (Moura and Brito 2011, Griebeler, 2013, 
Cademartori et al. 2013), Eucalyptus saligna (Pincelli et al. 2012), Eucalyptus globulus (Esteves et al. 2008), Pinus caribaea (Pincelli et al. 2012), Pinus caribaea var. hondurensis (Moura and Brito 2011) and Pinus pinaster (Esteves et al. 2008).

According to Varga and Van Den Zee (2008), dissolution, oxidization and decomposition of extractives are the main reasons for color changes and modification of surface chemistry. Components that absorb visible light are formed during heat treatment. Examples are the formation of condensation products, low molecular-weight phenolic substances and oxidation products such as quinine like substances from lignin. Splitting of aliphatic side chains in lignin and condensation reactions (Chen et al. 2012a), percentage decline of hydroxyl groups and percentage increase of acid groups and esterified structure were found after heat treatment and caused darker color (Chen et al. 2012b, Yildiz et al. 2013).

For the chromatic coordinate $\mathrm{a}^{*}$, positive values are related to high levels of red color. In eucalyptus wood, a reduction of this parameter was observed, but in pinus wood an increase was observed. Pincelli et al. (2012) observed the same behavior in Eucalyptus saligna and Pinus caribaea wood, at different temperatures $\left(120-180{ }^{\circ} \mathrm{C}\right)$. This change depends on the species and final temperature. This is related to volatilization of some chemical compounds that give a red color (Moura and Brito 2011, Zanuncio et al. 2014b) and is strongly correlated with the concentration of phenolic extractives (Gierlinger et al. 2004, Zanuncio et al. 2014b). The presence of polar extractives is reported to influence color variations during thermal modification (Fan et al. 2010).

For the chromatic coordinate $b^{*}$, positive values are related to high levels of yellow color. In both species, a decrease in these values was observed. The behavior found for pinus wood is not in agreement with the findings of Pincelli et al. (2012), who observed a maximum gain in yellow color with heating to $160^{\circ} \mathrm{C}$. Griebeler (2013) did not observed variation in b* in Eucalyptus grandis thermally modification at $160^{\circ} \mathrm{C}$.

Color saturation $(\mathrm{C})$ was greater in pinus than eucalyptus. Treated pinus wood had similar saturation as natural eucalyptus wood. $\mathrm{C}$ is calculated as a function of chromatic coordinates $\mathrm{a}^{*}$ and $\mathrm{b}^{*}$, and is dependent on the pattern of their variation. In both species, color saturation decreased after modification. An increase in this parameter was observed in Pinus caribaea (Pincelli et al. 2012) and in Eucalyptus grandis (Griebeler 2013) until $160^{\circ} \mathrm{C}$. Fan et al. (2010) found that decreases are mainly influenced by $b^{*}$ values, while changes in $a^{*}$ values have less effect on color saturation.

For hue angle $\left(\mathrm{h}^{*}\right)$, both species had the same behavior, a decrease in the parameter. Other studies have obtained the same results (Pincelli et al. 2012, Griebeler 2013). The reduction of tonality differences between species by heat treatment is reportedly a tool for homogenizing wood tonality and adding value to non-traditional species (Esteves et al. 2008).

The colorimetric parameters of the species studied, based on the classification table reported by Camargos and Gonçalez (2001), show the difference in wood color: natural eucalyptus was classified as rose and thermally modified as dark brown; natural pine was classified as light yellow and thermally modified as brown olive.

Color variation between natural and thermal treated wood (Table 3 ) shows reduction of luminosity (negative DL) for both species; reduction of parameters $\mathrm{a}^{*}$ and $\mathrm{b} *$ for Eucalyptus grandis, and reduction of parameter $\mathrm{b}^{*}$ and increase of parameter $\mathrm{a}^{*}$ for Pinus taeda, resulting in an appreciable change in total color (DE). Values higher than 12 in (DE) are classified as very appreciable by Hikita et al. (2001).

Table 3: Variation in colorimetric parameters in samples of Eucalyptus grandis and Pinus taeda after thermal modification, in relation to natural wood.

\begin{tabular}{|l|c|c|c|c|}
\hline Treatment & $\Delta \mathbf{L}^{*}$ & $\Delta \mathbf{a}^{*}$ & $\Delta \mathbf{b}^{*}$ & $\boldsymbol{\Delta E}$ \\
\hline E. grandis x E. grandis $160^{\circ} \mathrm{C}$ & $-29,32$ & $-4,39$ & $-7,39$ & 30,77 \\
\hline P. taeda x P. taeda $160^{\circ} \mathrm{C}$ & $-24,68$ & 3,04 & $-14,08$ & 28,93 \\
\hline
\end{tabular}


Changes in wood color after heating are the result of several reactions (dehydration, hydrolysis, oxidation), principally involving extractives, and contribute to formation of double bonds, carbonyl functionalities and quinoid structures, but lignin and hemicellulose can also play important roles in formation of color substances during heat treatment (Chen et al. 2014). The extractives can form new color substances during heat treatment. The possible condensation of tannins and the oxidation of the hydroxyl groups in flavone molecules can be a reason for formation of new color substances (Fan et al. 2010).

Heat modification has a negative effect on light reflection (Figure 2). Low reflection rate of violet, blue and green light, between 400-520 nm, contribute to a dark brown color (Fan et al. 2010). The reflectance of thermally treated wood increased with, a maximum in the red region $(620-740 \mathrm{~nm})$. Esteves et al. (2008) observed that in pine wood, reflectance increased more in radial planes, and in eucalyptus wood in tangential sections, and that the relationship between chemical composition and lightness decrease for pine with a strong correlation $\left(\mathrm{R}^{2}=0,96\right)$.

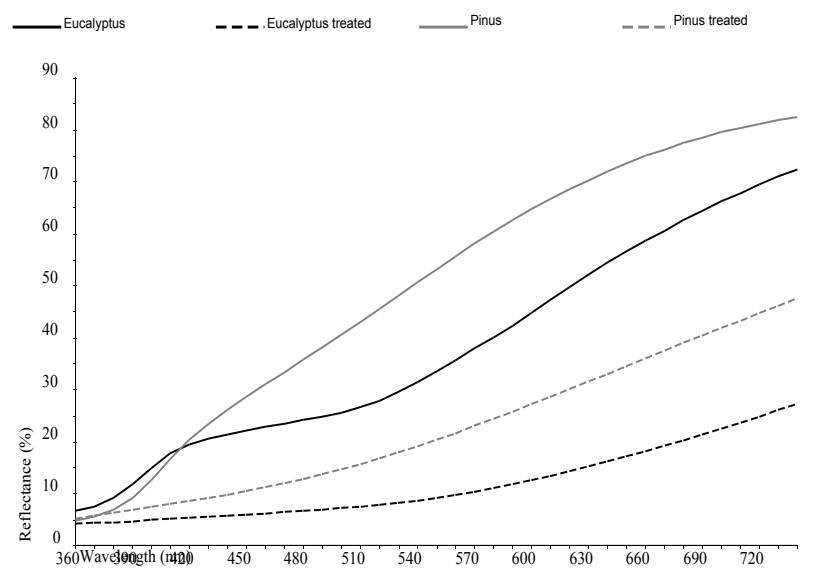

Figure 2: Reflectance curves of visible spectra of studied species.

The better photostability of thermally treated wood is partially explained by the increase of lignin stability by condensation and increase in phenol content during the heat treatment. Persze and Tolvaj (2012) presented results about photodegradation of wood and summarized the primary changes in the decomposition of lignin, with the liberation of free phenoxyl radicals. These radicals react with oxygen to produce carbonyl chromophoric groups, which are responsible for discoloration.

\section{Near Infrared spectroscopy}

The mean spectral patterns of natural and thermally modified wood (Figure 3) show the same main lignocellulosic composition (Schwanninger et al. 2011, Tsuchikawa and Schwanninger 2013) and some baseline influence. According to Schwanninger et al. (2011), the region near 2334, 227, 1471$1473 \mathrm{~nm}$ is related to cellulose and hemicelluloses; wavelengths near 2134, 1440, 1447-1448 nm are related to lignin and extractives; bands at $1927 \mathrm{~nm}$ and region from 1435 to $1438 \mathrm{~nm}$ are attributed to water content. Changes in these regions after thermal treatment are attributed to changes on $\mathrm{OH}$ groups (Mitsui et al. 2008). 


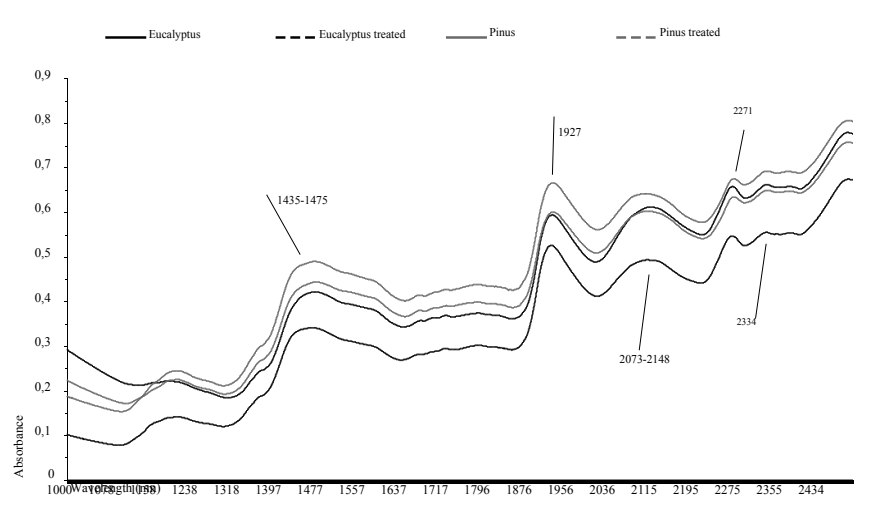

Figure 3: Mean NIR spectra of studied species.

Wavenumbers between 1500-1900 nm are related to first combinations of harmonics from $\mathrm{CH}$, $\mathrm{CH}_{2}, \mathrm{CH}_{3}$, and $\mathrm{ArCH}$, forming the first harmonic region of $\mathrm{RCO}_{2} \mathrm{H}$ and $\mathrm{RCO}_{2}-\mathrm{R}$ and $\mathrm{H}_{2} \mathrm{O}$ and the second harmonic of $\mathrm{C}=\mathrm{O}$ (hemicelluloses). These regions, present in hemicellulose and amorphous cellulose, are more sensitive to temperature, resulting in changes after thermal treatment. Changes in the 1705$1724 \mathrm{~nm}$ region show degradation of carbohydrates and in acetylating reactions in hemicelluloses, while at $1674 \mathrm{~nm}$, alterations are related to lignin (Michell and Schimleck 1996, Fackler and Schwanninger 2010).

The behavior of wood components due to thermal degradation are different in function of polymer composition and whether they are isolated or combined in the wood cell matrix (Popescu et al. 2011). Also evaluated species and final temperature and heating rate present influence in final spectra (Mehrotra et al. 2010).

\section{Spectral analysis}

Principal component analysis (PCA) of near-infrared (Figure 4a) and visible spectra (Figure $4 \mathrm{~b})$ shows a better distinction of species and treatment in the visible range. In NIR analysis, MSC pretreatment was applied and natural wood (E. grandis and $P$. taeda) were grouped and distinct from the treated wood. Also, the influence of surface color is evident in distinguishing samples after thermal treatment. In the visible range, all samples are distinct (natural and treated wood and both species). Bächle et al. (2012) also reported the possibility of distinguishing thermally treated beech, spruce and ash, and recommended the application of PCA in quality control.

In NIR spectra (Figure 5a), wavelength at 1316, 1406, 1921, 2120, 2175 and $2269 \mathrm{~nm}$ present more influence in discrimination of species and treatments. This bands are related to cell wall components, cellulose, hemicelluloses and lignin, also extractives present in species. Some influence of moisture content is visible in region near $1921 \mathrm{~nm}$, showing that degradation process of wood components is influenced by species in the same heat conditions. In visible spectra (Figure 5b), almost all wavelengths present influence in samples distinction, because natural reflectance of species is based on color pigments of each one: i) region from $495-589 \mathrm{~nm}$ are related to green and yellow color and region from $670-700 \mathrm{~nm}$ is attributed to red color. Eucalyptus wood and samples treated are red to brown, and pinus wood is pale yellow. 


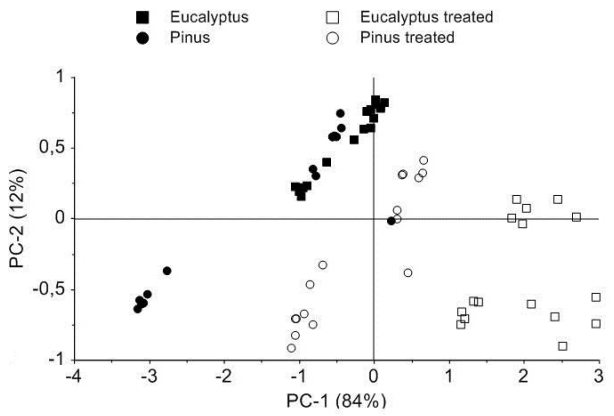

a)

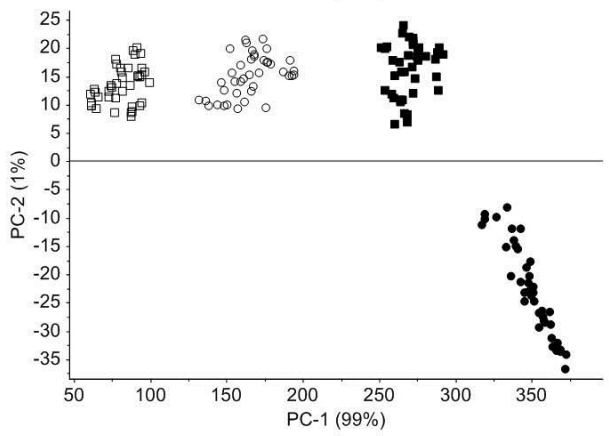

b)

Figure 4: Principal component analysis of (a) NIR spectra and (b) visible spectra (B).
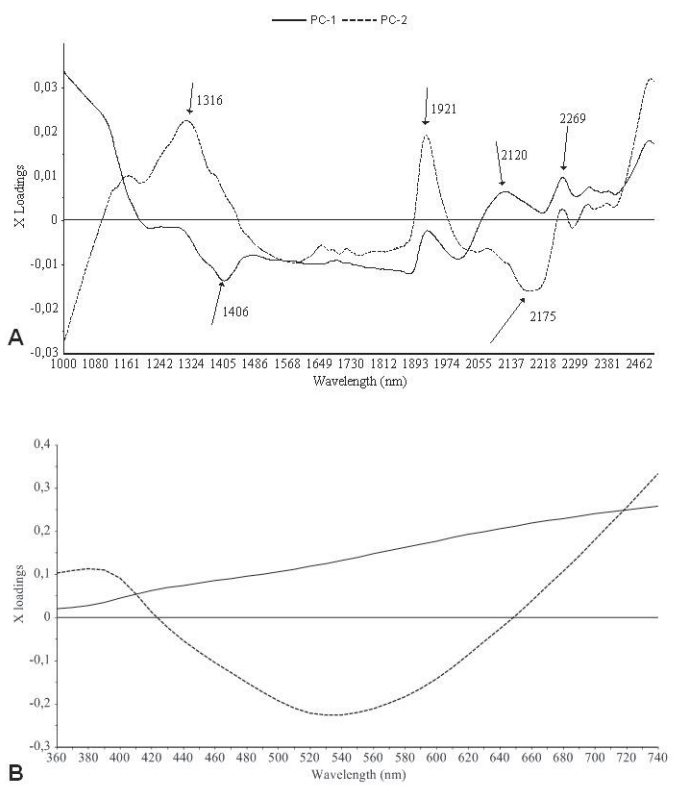

Figure 5: X-loadings of NIR spectra (a) pretreated with MSC and (b)visible spectra 
Prediction of chemical composition of samples was done based on spectra pretreated with MSC. Different species (Eucalyptus and Pinus) and treatment (natural and thermally treated) were evaluated from visible and near spectra by partial least square (PLS) analysis. Error of prediction and correlation coefficients of models based on natural and thermally treated wood (Table 4) showed the potential application of NIR and visible spectra to predict lignin, holocellulose and total extractives of Eucalyptus grandis and Pinus taeda wood, both natural and thermally modified at $160{ }^{\circ} \mathrm{C}$.

Table 4: PLS model for chemical composition prediction studied species.

\begin{tabular}{|l|c|c|c|c|c|}
\hline & \multicolumn{3}{|c|}{ Calibration } & \multicolumn{2}{c|}{ External prediction } \\
\hline & PC Number & $\mathbf{R}^{\mathbf{2}}$ & RMSEC & $\mathbf{R}^{\mathbf{2}}$ & RMSEP \\
\hline NIR spectra & & & & & \\
\hline Lignin & 3 & 0,92 & 0,96 & 0,87 & 1,23 \\
\hline Holocellulose & 3 & 0,92 & 1,18 & 0,93 & 1,08 \\
\hline Total Extractives & 3 & 0,89 & 0,94 & 0,86 & 1,08 \\
\hline Visible spectra & & & & & \\
\hline Lignin & 2 & 0,92 & 0,93 & 0,92 & 0,93 \\
\hline Holocellulose & 2 & 0,93 & 1,10 & 0,88 & 1,50 \\
\hline Total Extractives & 2 & 0,90 & 0,90 & 0,76 & 1,43 \\
\hline
\end{tabular}

Literature report prediction of chemical properties based on near infrared spectra (Karlinasari et al. 2014, Via et al. 2014) and the influence of sample preparation (Hein et al. 2009), but analyses of visible spectra are scarce (Prades et al. 2014).

These results indicate the possibility of applying VIS/NIR on production lines in industries making solid wood products and where the final quality depends on chemical composition of raw material. The possibility of using color measurements in industry to predict chemical properties can be an innovation for quality control in the furniture and flooring industry, because the components can influence external aspects by reacting with varnish and paints, for example. Our results shows the potential of color parameters, for its application in industry, other analysis with more samples, species and thermal treatments must be done.

\section{CONCLUSIONS}

Thermal treatment changed chemical composition and color of wood treated at $160^{\circ} \mathrm{C}$ in a saturated steam atmosphere with efficient elimination of oxygen. Extractives and lignin content increased and holocellulose content decreased in Eucalyptus grandis and Pinus taeda.

An appreciable change in total color between natural and thermal treated wood was observed, with reduction in luminosity for both species. A decrease in $\mathrm{a}^{*}$ and $\mathrm{b}^{*}$ chromatic coordinate was verified for Eucalyptus grandis and reduction of parameter $\mathrm{b}^{*}$ and increase of parameter $\mathrm{a}^{*}$ for Pinus taeda. Visible spectra were able to distinguish all samples and treatments.

NIR spectra showed changes in chemical composition of cell wall after thermal treatment and the influence of species on wood degradation process. Data were efficient in distinction of natural and treated wood.

NIR and visible spectra were used to predict chemical composition of Eucalyptus grandis and Pinus taeda in natural condition and after thermal treatment with $\mathrm{R}^{2}$ from 0,76 to 0,92 showing its potential, and must be tested on line in industry. 


\section{REFERENCES}

Acquah, G.E.; Via. B.K.; Billor, N.; Fasina, O.O.; Eckhardt, L.G. 2016. Identifying plant part composition of forest logging residue using infrared spectral data and linear discriminant analysis. Sensors 16(9): 1375.

ASTM. 2012. Standard practices for infrared multivariate, quantitative analysis. ASTM. E165505. 2012.

Bächle, H.; Zimmer, B.; Wegener, G. 2012. Classification of thermally modified wood by FTNIR spectroscopy and SIMCA. Wood Science and Technology 46 (6):1181-1192.

Bächle, H.; Zimmer, B.; Windeisen. E.; Wegener, G. 2010. Evaluation of thermally modified beech and spruce wood and their properties by FT-NIR spectroscopy. Wood Science and Technology 44 (3):421-433.

Bekhta, P.; Proszyk, S.; Lis, B.; Krystofiak, T. 2014. Gloss of thermally densified alder (Alnus glutinosa Goertn.), beech (Fagus sylvatica L.), birch (Betula verrucosa Ehrh.), and pine (Pinus sylvestris L.) wood veneers. European Journal of Wood and Wood Products 72 (6):799-808.

Brito, J.O.; Silva, F.G.; Leão, M.M.; Almeida, G. 2008. Chemical composition changes in eucalyptus and pinus woods submitted to heat treatment. Bioresource Technology 99 (18): 8545-8548.

Cademartori, P.H.G.; Schneid, E.; Gatto, D.A.; Stangerlin, D.M.; Beltrame, R. 2013. Thermal modification of Eucalyptus grandis wood: variation of colorimetric parameters. Maderas-Cienc Tecnol 15(1): 57-64.

Camargos, J.A.A.; Gonçalez, J.C. 2001. A colorimetria aplicada como instrumento na elaboração de uma tabela de cores de madeira. Brasil Florestal 71: 30-41.

Chen, Y.; Fan, Y.; Gao, J.; Li, H. 2012a. Coloring characteristics of in situ lignin during heat treatment. Wood Science and Technology 46(1): 33-40.

Chen, Y.; Fan, Y.; Gao, J.; Li, H. 2012b.The effect of heat treatment on the chemical and color change of black locus (Robinia pseudoacacia) wood flour. BioResources 7(1): 1157-1170.

Chen, Y.; Tshabalala, M.A.; Gao, J, Stark, N.M.; Fan, Y. 2014. Color and surface chemistry changes of extracted wood flour after heating at $120^{\circ} \mathrm{C}$. Wood Science and Technology 48 (1):137-150.

Conte, B.; Missio, A.L.; Pertuzzatti, A.; Cademartori, P.H.G.; Gatto, D.A. 2014. Physical and colorimetric properties of Pinus elliottii var. elliottii thermally treated wood. Scientia Forestalis 42(104): 555-563.

De Paula, M.H.; Gonçalez, J.C.; De Mesquita, R.R.S.; Lima, C.M.; Rodrigues, T.O. 2016. Heat treatment effect on the color of the heartwood and sapwood in a Sapucaia tree (Lecythis pisonis Cambess). Australian Journal Basic and Applied Science 10(13): 108-115.

Esteves, B.; Pereira, H. 2008. Quality assessment of heat-treated wood by NIR spectroscopy. Holz als Roh- und Werkstoff 66 (5):323-332.

Esteves, B.; Videira, R.; Pereira, H. 2008. Heat-induced colour changes of pine (Pinus pinaster) and eucalypt (Eucalyptus globulus) wood. Wood Science and Technology 42(5): 369-384. 
Esteves, B.; Videira, R.; Pereira, H. 2011. Chemistry and ecotoxicity of heat-treated pine wood extractives. Wood Science and Technology 45 (4):661-676.

Esteves, B.M.; Pereira, H.M. 2009. Wood modification by heat treatment: a review. BioResources 4(1): 370-404.

Fackler, K.; Schwanninger, M. 2010. Polysaccharide degradation and lignin modification during brown rot of spruce wood: a polarised Fourier transform near infrared study. Journal of Near Infrared Spectroscopy 18(6):403-416.

Fan, Y.; Gao, J.; Chen, Y. 2010. Colour response of black locust (Robinia pseudoacacia L.) to solvent extraction and heat treatment. Wood Science and Technology 44 (4): 667-678.

Fearn, T.; Riccioli, C.; Garrido-Varo, A.; Guerrero-Ginel, J.E. 2009. On the geometry of SNV and MSC. Chemometrics and Intelligent Laboratory Systems 96(1): 22-26.

Freitas, A. S.; Gonçalez, J.C.; Del Menezzi, C.H. 2016. Thermomechanical treatment and the effects on the properties of Simarouba amara (Aubl.). Floresta e Ambiente 23(4): 565-572.

Garcia, R.A.; Oliveira, N.S.; Nascimento, A.M.; Souza, N.D. 2014. Colorimetry of woods from Eucalyptus and Corymbia genus and its correlation with density. Cerne 20(4): 509-517.

Gierlinger, N.; Jacques, D.; Grabner, M.; Wimmer, R.; Schwanninge, M.; Rozenberg, P.; Pâques L.E. 2004. Colour of larch heartwood and relationships to extractives and brown-rot decay resistance. Trees 18 (1):102-108.

Gonzáles-Peña, M.M.; Curling, S.F.; Hale, M.D.C. 2009. On the effect of heat on the chemical composition and dimensions of thermally-modified wood. Polymer Degradation and Stability 94(12): 2184-2193.

Griebeler, C.G.O. 2013. Colorimetria da madeira de Eucalyptus grandis W.Hill ex Maiden modificada termicamente. Master thesis of the Federal University of Parana.

Hein, P.R.G.; Lima, J.T.; Chaix, G. 2009. Effects of sample preparation on NIR spectroscopic estimation of chemical properties of Eucalyptus urophylla S.T. Blake wood. Holzforschung 64(1): $45-54$.

Hikita, Y.; Toyoda, T.; Azuma, M. 2001. Weathering testing of timber-discoloration. In: Inamura Y. High performance utilization of wood for outdoor uses. Kyoto, Japão, Press-Net.

Huang, X.; Kocaefe, D.; Kocaefe, Y.; Pichette, A. 2018. Combined effect of acetylation and heat treatment on the physical, mechanical and biological behavior of jack pine (Pinus banksiana) wood. European Journal of Wood and Wood Products 76: 525-540.

Karlinasari, L.; Sabed, M.; Wistara, I.N.J.; Purwanto, Y.A. 2014. Near infrared (NIR) spectroscopy for estimating the chemical composition of (Acacia mangium Willd.) wood. Journal of Indian Academic Wood Science 11(2): 162-167.

Kumar, N.; Bansal, A.; Sarma, G.S.; Rawal, R.K. 2014. Chemometrics tools used in analytical chemistry: An overview. Talanta 123:186-199.

Kuzman, M.K.; Kutnar, A.; Ayrilmis, N.; Kariz, M. 2015. Effect of heat treatment on mechanical properties of selected wood joints. European Journal of Wood Products 73: 689-691.

Li, M. Y.; Cheng, S. C.; Li, D.; Wang, S.N.; Huang, A. M.; Sun, S.Q. 2015. Structural characterization of steam heat treated Tectona grandis wood analyzed by FT-IR and 2D-IR correlation spectroscopy. Chinese Chemical Letters 26(2) 221-225. 
Mehrotra, R.; Singh, P.; Kandpal, H. 2010. Near infrared spectroscopic investigation of the thermal degradation of Wood. Thermochimica Acta 507-508: 60-65.

Méndez-Mejías, L.D.; Moya, R. 2016. Effects on density, shrinking, color changing and chemical surface analysis through FTIR of Tectona grandis thermo-treated. Scientia Forestalis 44(122): 811820.

Michell, A.J.; Schimleck, L.R. 1996. NIR spectroscopy of woods from Eucalyptus globulus. Appita Journal 49:23-26.

Militz, H.; Altgen, M. 2016. Processes and properties of thermally modified wood manufactured in Europe. In: Deterioration and protection of sustainable biomaterials. ACS Symposium Series 1158(16) 269-285.

Mitsui, K. 2004. Changes in the properties of light-irradiation wood with heat-treatment. Part 2. Effect of light-irradiation time and wavelength. Holz als Roh-und Werkstoff 62(1): 23-30.

Mitsui, K.; Inagaki, T.; Tsuchikawa, S. 2008. Monitoring of hydroxyl groups in wood during heat treatment using NIR spectroscopy. Biomacromolecules 9(1): 286-288.

Moura, L.F.; Brito, J.O. 2011. Effect of thermal rectification on colorimetric properties of Eucalyptus grandis and Pinus caribaea var hondurensis woods. Scientia Forestalis 39(89):69-76.

Olarescu, M.C.; Campean, M.; Ispas, M.; Cosereanu, C. 2014. Effect of thermal treatment on some properties of lime wood. European Journal of Wood Products 72(4): 559-562.

Persze, L.; Tolvaj, L. 2012. Photodegradation of wood at elevated temperature: colour change. Journal of Photochemistry and Photobiology B: Biology 108: 44-47.

Pertuzzatti, A. 2016. Physical properties of Pinus elliottii var. elliottii thermally treated wood under two different atmospheres. Ciência da Madeira 7(15): 7-15, 2016.

Pincelli, A.L.P.S.M.; Moura, L.F.; Brito, J.O. 2012. Effect of thermal retification on colors of Eucalyptus saligna and Pinus caribaea woods. Maderas-Cienc Tecnol 14(2): 239-248.

Poletto, M.; Zattera, A.J.; Santana, R.M.C. 2012. Thermal decomposition of wood: Kinetics and degradation mechanisms. Bioresource Technology 126: 7-12.

Popescu, M.C.; Popescu, C.M.; Lisa, G.; Sakata, Y. 2011. Evaluation of morphological and chemical aspects of different wood species by spectroscopy and thermal methods. Journal of Molecular Structure 988: 65-72.

Poubel, D.S.; Garcia, R.A.; Santos, W.A.; Oliveira, G.L.; Abreu, H.S. 2013. Efeito da termorretificação nas propriedades físicas e químicas da madeira de Pinus caribaea. Cerne 19 (3): $391-98$.

Prades, C.; Gomes-Sanchez, I.; Garcia-Olmo, G.; Gonzales- Hernadez, F.; Gonzales-Adrados J.R. 2014. Application of VIS/NIR spectroscopy for estimating chemical, physical and mechanical properties of cork stoppers. Wood Science and Technology 48 (4):811-830.

Schwanninger, M.; Hinterstoisser, B.; Gierlinger, N.; Wimmer, R.; Hanger, J. 2004. Application of fourier transform near infrared spectroscopy (FT-NIR) to thermally modified wood. Holz als Rohund Werkstoff 62 (6):483-485.

Schwanninger, M.; Rodrigues, J.C. Fackler, K. 2011. A review of band assignments in near infrared spectra of wood and wood components. Journal of Near Infrared Spectroscopy 19: 287-308. 
Severo, E.T.; Calonego, F.W.; Sansígolo, C.A. 2012. Physical and chemical changes in juvenile and mature woods of Pinus elliottii var. elliottii by thermal modification. European Journal of Wood and Wood Products 70(5): 741-747.

Silva, M.R. 2012. Efeito do tratamento térmico nas propriedades químicas, físicas e mecânicas em elementos estruturais de Eucalyptus citriodora e Pinus taeda. PhD Thesis of the University of São Paulo.

Stangerlin, D.M.; Costa, A.F.; Gonçalez, J.C.; Pastore, T.C.M.; Garlet, A. 2013. Monitoring of biodeterioration of three Amazonian wood species by the colorimetry technique. Acta Amazonica 43: 429-438.

TAPPI. 2004. Solvent extractives of wood and pulp. T204 - om 97. 2004. In: Tappi Test Methods. TAPPI Press: Norcross, GA.

TAPPI. 2004. Ash in wood, pulp, paper and paperboard: combustion at $525^{\circ} \mathrm{C}$. T211 - om 02 . 2004. In: Tappi Test Methods. TAPPI Press: Norcross, GA

TAPPI. 2004. Acid-insoluble lignin in wood and pulp. T222 - om 02. 2004. In: Tappi Test Methods. TAPPI Press: Norcross, GA.

Tong, l.; Zhang, W. 2016. Using Fourier transform near-infrared spectroscopy to predict the mechanical properties of thermally modified southern pine wood. Applied Spectroscopy 70(10): 1-9.

Torres, S.S.; Jomaa, W.; Marc, F. Puiggali, J.R. 2012. Colour alteration and chemistry changes in oak wood (Quercus pedunculata Ehrh.) during plain vacuum drying. Wood Science Technology 46: $177-191$

Tsuchikawa, S.; Schwanninger, M. 2013. A review of recent near-infrared research for wood and paper (Part 2). Applied Spectroscopy Review 48:560-587.

Varga, D.; Van Der Zee, M.E. 2008. Influence of steaming on selected wood properties of four hardwood species. Holz als Roh-und Werkstoff 66(1): 11-18.

Via, B.K.; Zhou, C.; Acquah, G.; Jiang, W.; Eckhardt, L. 2014. Near infrared spectroscopy calibration for wood chemistry: which chemometric technique is best for prediction and interpretation? Sensors 14: 13532-13547.

Yildiz, S.; Tomak, E. D.; Yildiz, U. C.; Ustaomer, D. 2013. Effect of artificial weathering on the properties of heat treated wood. Polymer Degradation and Stability 98(8): 1419-1427.

Zanuncio, A.J.V.; Motta, J.P.; Da Silveira, T.A.; Farias, E.S.; Trugilho, P.F. 2014a. Pysical and colorimetric changes in Eucalyptus grandis wood after heat treatment. Bioresources 9(1): 293-302.

Zanuncio, A.J.V.; Nobre, J.R.C.; Motta, J.P.; Trugilho, P.F. 2014b. Química e colorimetria da madeira de Eucalyptus grandis w. Mill ex Maiden termorretificada. Revista Arvore38(4): 765-770.

Zanuncio, A.J.V.; Nobre, J.R.C.; Motta, J.P.; Trugilho, P.F. 2014c. Heat treatment and color of Eucalyptus grandis wood. Floresta e Ambiente 21(1): 85-90. 